\title{
Penerapan Data Mining dalam Mengelompokkan Jumlah Kematian Penderita COVID-19 Berdasarkan Negara di Benua Asia
}

\author{
Noviyanto \\ Universitas Gunadarma \\ e-mail: viyan@staff.gunadarma.ac.id
}

\begin{abstract}
Abstrak - COVID-19 disebabkan oleh SARS-CoV-2, yaitu virus jenis baru dari coronavirus (kelompok virus yang menginfeksi sistem pernapasan). Infeksi virus Corona bisa menyebabkan infeksi pernapasan ringan sampai sedang, seperti flu, atau infeksi sistem pernapasan dan paru-paru, seperti pneumonia. Maraknya penyebaran penyakit yang diakibatkan oleh virus COVID-19 yang telah ditetapkan sebagai pandemi oleh WHO pada tanggal 12 Maret 2020 , akibat virus COVID-19 banyak pasien yang terjangkit mengalami kematian. Dalam mengelompokkan jumlah kematian penderita Covid-19 menggunakan teknik data mining metode k-means clustering. Data diambil dari dari link https://www.worldometers.info/coronavirus/. Hasil dari penelitian ini adalah cluster jumlah kematian penderita Covid-19 kedalam 3 cluster. terdapat 4 negara dengan cluster tingkat tinggi yaitu: Turki, Iran, India dan China dengan cluster tingkat sedang sebanyak 4 negara yaitu : Pakistan, Indonesia, Jepang, dan Piliphina dan dengan cluster rendah adalah 41 negara lainnya.
\end{abstract}

Kata kunci: Data mining, Clustering, K-Means, Covid-19

Abstract - COVID-19 is caused by SARS-CoV-2, a new type of virus from coronavirus (a group of viruses that infects the respiratory system). Corona virus infections can cause mild to moderate respiratory infections, such as flu, or respiratory and lung system infections, such as pneumonia. The rise of the spread of diseases caused by the COVID-19 virus which has been established as a pandemic by WHO on March 12, 2020, due to the COVID-19 virus many patients who have contracted have died. In classifying the number of deaths of patients with Covid-19 using data mining techniques $k$-means clustering method. Data is taken from the link https://www.worldometers.info/coronavirus/. The results of this study are the cluster number of deaths of patients with Covid-19 into 3 clusters. there are 4 countries with high level clusters, namely: Turkey, Iran, India and China with medium level clusters as many as 4 countries namely: Pakistan, Indonesia, Japan, and the Philippines and with low clusters are 41 other countries.

Keywords: Data mining, Clustering, K-Means, Covid-19

\section{PENDAHULUAN}

Data mining adalah proses menganalisa data dari perspektif yang berbeda dan menyimpulkannya menjadi informasi-informasi penting yang dapat dipakai untuk meningkatkan keuntungan, memperkecil biaya pengeluaran, atau bahkan keduanya. Secara teknis, data mining dapat disebut sebagai proses untuk menemukan korelasi atau pola dari ratusan atau ribuan field dari sebuah relasional database yang besar (Angga Ginanjar Mabrur, 2012).

Pengelompokan Data Mining dibagi menjadi beberapa kelompok yaitu :

a. Deskripsi

Deskripsi merupakan cara untuk menggambarkan pola dan kecenderungan yang terdapat dalam data yang dimiliki.

b. Estimasi

Estimasi hampir sama dengan klasifikasi, kecuali variable target estimasi lebih ke arah numerik daripada ke arah kategori. Model yang dibangun menggunakan record lengkap yang menyediakan nilai variable target sebagai nilai prediksi.

c. Prediksi

Prediksi menerka sebuah nilai yang belum diketahui dan juga memperkirakan nilai untuk masa mendatang.

d. Klasifikasi

Dalam klasifikasi terdapat target variable kategori, misal penggolongan pendapatan dapat dipisahkan dalam tiga kategori, yaitu tinggi, sedang, dan rendah.

e. Pengklasteran

Merupakan pengelompokan record, pengamatan, atau memperhatikan dan membentuk kelas objekobjek yang memiliki kemiripan.

f. Asosiasi

Asosiasi bertugas menemukan atribut yang muncul dalam satu waktu. Dalam dunia bisnis lebih umum 
disebut analisis keranjang belanja (Maulana \& Fajrin, 2018).

Maraknya penyebaran penyakit yang diakibatkan oleh virus COVID-19 yang telah ditetapkan sebagai pandemi oleh WHO pada tanggal 12 Maret 2020 , akibat virus COVID-19 banyak pasien yang terjangkit mengalami kematian. Data yang diperoleh dari link https://www.worldometers.info/coronavirus/ menunjukan angka kematian sebesar 329,731 dari seluruh negara-negara di benua Asia berdasarkan data update Mei 21, 2020, 03:12 GMT. Begitu juga di negara-negara benua Asia banyak yang mengalami kematian. Data kematian akibat penyebaran virus COVID-19 menunjukkan angka sebesar 25,851. Berdasarkan data yang di peroleh dapat dilakukan pengelompokkan angka kematian penyebaran virus COVID-19 yang nanti dapat menjadi masukkan kepada negara-negara di benua Asia agar meningkatkan kualitas penanganan pasien penderita virus COVID-19.

\section{Rumusan Masalah}

a. Meningkatnya angka kematian akibat penyebaran virus COVID-19 di negara-negara Asia.

b. Perlu adanya pengelompokkan data kematian akibat penyebaran virus COVID-19.

\section{Batasan Masalah}

Supaya pembahasan pada penelitian ini tidak terlalu luas dan lebih fokus maka dibatasi hanya pada :

1. Penambangan data dari https://www.worldometers.info/coronavirus/

2. Pengelompokkan data angka kematian akibat penyebaran virus COVID-19 di negara-negara Asia

3. Uji coba data yang digunakan menggunakan software RapidMiner .

\section{Tujuan Penelitian}

Penelitian ini bertujuan menghasilkan cluster data kematian akibat penyebaran virus COVID-19 berdasarkan negara-negara di Asia menggunakan teknik data mining metode K-Means Clustering.

\section{a. Data Mining}

Data mining adalah analisa terhadap data untuk menemukan hubungan yang jelas serta menyimpulkannya yang belum diketahui sebelumnya dengan cara terkini dipahami dan berguna bagi pemilik data tersebut. Data mining adalah metoda yang digunakan untuk mengekstraksi informasi prediktif tersembunyi pada database, ini adalah teknologi yang sangan potensial bagi perusahaan yang sangat potensial bagi perusahaan dalam memberdayakan data warehouse. Secara garis besar,data mining dapat dikelompokkan menjadi 2 kategori utama,yaitu:

1. Deskriptive mining, yaitu proses untuk menemukan karakteristik penting dari data dalam satu basis data. Teknik data mining yang termasuk descriptive mining adalah clustering, asosiation, dan sequential mining.

2. Predictive, yaitu proses untuk menemukan pola dari data dengan menggunakan beberapa variable lain di masa depan.Salah satu teknik yang terdapat dalam predictive mining adalah klasifikasi. Secara sederhana data mining biasa dikatakan sebagai proses penyaring atau "menambang" pengtahuan dari sejumlah data yang besar.Istilah lain untuk data miing adalah Knowlegde Discovery in Database (KDD)(Darmi \& Setiawan, 2016).

\section{b. Pengelompokan Data Mining}

Algoritma Clustering mengelompokan satu setdokumen ke dalam himpunan bagian atau klaster. Tujuan algoritma klaster adalah menciptakan klaster yang koheren secara internal, tetapi jelas berbeda satu sama lain. Dengan kata lain, dokumen dalam sebuah klaster harus semirip mungkin; dan dokumen dalam satu klaster harus sebeda mungkin dari dokumen dalam klaster lainnya.

Clustering merujuk pada pengelompokan dokumen, observasi atau kasus pada kelas yang objeknya mirip. Klaster adalah kumpulan dokumen yang mirip satu sama lain dan berbeda dengan dokumen pada klaster lain. Clustering berbeda dengan Clasification, pada clustering tidak ada target variabel untuk dikelompokkan. Algoritma clustering mencoba untuk membagi kumpulan data menjadi klaster yang anggotanya relatif sama, dimana kemiripan dokumen di klaster yang sama tinggi, dan kemiripan dokumen di klaster lain kecil. Dengan kata lain, seperti pada Gambar 1, Algoritma clustering mencoba membuat klaster dokumen yang between-clusters variation (BCV) lebih tinggi dibandingkan dengan within- cluster cluster variation (WCV) (Robani \& Widodo, 2016).

\section{c. K-Means Clustering}

K-means adalah salah satu bentuk pengelompokan yang paling sederhana. Prosedurnya sederhana dan mudah untuk mengklasifikasikan data yang diberikan melalui sejumlah cluster. Penentuan centroid dilakukan dengan cara mengambil data pertama sebagai centroid pertama, data kedua sebagai centroid kedua, dan seterusnya hingga jumlah centroid yang diperlukan. Langkah berikutnya adalah dengan menghitung jarak dari titik yang akan di cluster ke setiap centroid yang ada dan dikelompokkan sesuai dengan jarak terdekat kepada centroid-nya. Bila semua titik 
sudah masuk kedalam pengelompokan maka langkah pertama selesai. Kemudian langkah berikutnya, kita perlu menghitung kembali kcentroid baru sebagai barycenters dari kelompok yang dihasilkan. Setelah memiliki k-centroid yang baru, pengelompokan di uji kembali terhadap kcentroid (Kristanto, A, \& S, 2016).

\section{METODOLOGI PENELITIAN}

Pada rancangan penelitian ini penulis akan menguraikan metodologi dan kerangka penelitian kerja yang digunakan dalam menyelesaikan masalah penelitian. Metodologi penelitian ini digunakan secara sistematik agar mendapatkan alur kerja yang baik sehingga dapat digunakan sebagai pedoman untuk peneliti selanjutnya yang akan melaksanakan penelitian ini agar hasil yang dicapai tidak menyimpang dari tujuan yang di inginkan dan dapat terlaksana dengan lebik baik dan sesuai dengan tujuan yang telah ditetapkan. Berikut diagram alir model penelitian disajikan dalam rancangan flowchart dapat dilihat dari gambar 1.

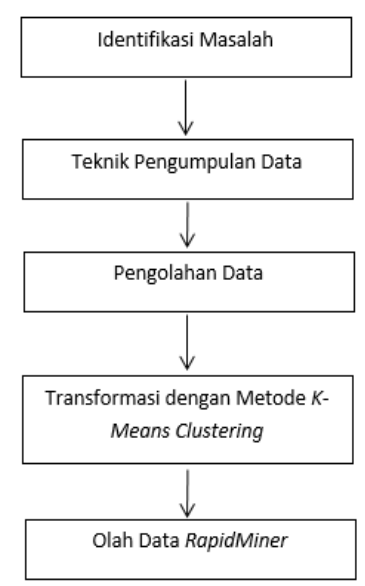

Gambar 1. Flowchart Kerangka Kerja Penelitian

Proses alur flowchart pada gambar 1 adalah sebagai berikut :

1. Identifikasi Masalah

Pengenalan suatu masalah, dan tahap awal dalam proses penelitian. Meningkatnya angka kematian akibat penyebaran virus COVID-19 di negara-negara di benua Asia.

2. Teknik Pengumpulan Data

Data penelitian ini diperoleh dari website dengan situs url https://www.worldometers.info/coronavirus/ mengenai data penyebaran virus COVID-19.

3. Pengolahan Data

Pada tahapan ini, data diolah untuk mendapatkan hasil yang kemudian dapat dikelola ke tahap berikutnya, sehingga mengghasilkan informasi yang tepat.

4. Transformasi dengan $K$-Means Clustering Transformasi data, data yang berjenis alfabet seperti nama negara terlebih dahulu harus dilakukan proses inisialisasi data terlebih dahulu ke dalam bentuk angka/numerical. Kemudian mengelompokkan data yang sudah ada dalam tiga kelompok yaitu tinggi, sedang, dan rendah dengan menggunakan metode $k$ means clustering.

5. Olah Data dengan RapidMiner

Dalam pengujian data menggunakan sebuah aplikasi RapidMiner. Dengan menggunakan software RapidMiner kita akan membandingkan bagaimana hasil pengolahan data secara manual dengan pengolahan data menggunakan sebuah software.

\section{HASIL DAN PEMBAHASAN}

\section{Analisis Data}

Analisis data merupakan cara yang digunakan untuk menjawab masalah penelitian melalui prosedur pengelolahannya terutama masalah yang berkaitan dengan penelitian. Data yang diperoleh untuk penelitian ini adalah data kematian penderita Covid-19 berdasarkan Negara-Negara di Benua Asia pada tanggal 21 Mei 2019.

\begin{tabular}{|l|l|r|l|l|r|}
\hline No & \multicolumn{1}{|c|}{ Negara } & $\begin{array}{c}\text { Total } \\
\text { Kematian }\end{array}$ & No & Negara & $\begin{array}{c}\text { Total } \\
\text { Kematian }\end{array}$ \\
\hline 1 & Turkey & 4,222 & 26 & Uzbekistan & 13 \\
\hline 2 & Iran & 7,183 & 27 & Tajikistan & 41 \\
\hline 3 & India & 3,434 & 28 & Kyrgyzstan & 14 \\
\hline 4 & China & 4,634 & 29 & Maldives & 4 \\
\hline 5 & Saudi Arabia & 339 & 30 & Hong Kong & 4 \\
\hline 6 & Pakistan & 985 & 31 & Sri Lanka & 9 \\
\hline 7 & Qatar & 16 & 32 & Lebanon & 26 \\
\hline 8 & Singapore & 22 & 33 & Cyprus & 17 \\
\hline 9 & Bangladesh & 386 & 34 & Georgia & 12 \\
\hline 10 & UAE & 233 & 35 & Jordan & 9 \\
\hline 11 & Indonesia & 1,242 & 36 & Taiwan & 7 \\
\hline 12 & Kuwait & 124 & 37 & Nepal & 2 \\
\hline 13 & Israel & 279 & 38 & Palestine & 2 \\
\hline 14 & Japan & 768 & 39 & Vietnam & 0 \\
\hline 15 & Philippines & 842 & 40 & Myanmar & 6 \\
\hline 16 & S. Korea & 264 & 41 & Yemen & 30 \\
\hline 17 & Afghanistan & 187 & 42 & Brunei & 1 \\
\hline 18 & Bahrain & 12 & 43 & Mongolia & 0 \\
\hline 19 & Malaysia & 114 & 44 & Cambodia & 0 \\
\hline 20 & Kazakhstan & 35 & 45 & Syria & 3 \\
\hline 21 & Oman & 30 & 46 & Macao & 0 \\
\hline 22 & Armenia & 67 & 47 & Timor-Leste & 0 \\
\hline 23 & Iraq & 134 & 48 & Bhutan & 0 \\
\hline 24 & Azerbaijan & 43 & 49 & Laos & 0 \\
\hline 25 & Thailand & 56 & & & \\
\hline & & & & & \\
\hline
\end{tabular}

\section{Perhitungan Manual K-Means Clustering}

a. Menentukan jumlah data yang akan di cluster, dengan sampel data kematian pasien covid-19 Asia menurut negara dengan jumlah data sebanyak 49 Negara.

b. Menentukan nilai k jumlah cluster sebanyak 3cluster yaitu cluster tinggi dan cluster rendah.

c. Menentukan nilai centroid awal yang telah ditentukan secara random, cluster tinggi (C1), cluster sedang (C2), dan cluster rendah (C3).

Berikut adalah nilai centroid data awal pada iterasi 1: 
Tabel 2. Centroid Awal Iterasi 1

\begin{tabular}{|c|c|c|}
\hline C1 & Maximum & 985,000 \\
\hline C2 & Average & 105,239 \\
\hline C3 & Minimum & 0,000 \\
\hline
\end{tabular}

d. Setelah data niai pusat cluster ditentukan, selanjutnya menghitung jarak setiap data terhadap pusat cluster yang dilakukan dengan titik pusan pada cluster pertama. Berikut adalah perhitungannya:

$\mathrm{D}(1.1)=\sqrt{(985,000-4,222)^{2}}=$ 980,778

Perhitungan dilakukan sampai D(1.49).

Selanjutnya perhitunggan pada cluster 2 rata-rata dengan titik pusat centroid:

$\mathrm{D}(2.1)=\sqrt{(105,239-4,222)})^{2}=$ 101,017

Perhitungan dilakukan sampai D (2.49). Selanjutnya perhitunggan pada cluster 3 rata-rata dengan titik pusat centroid:

$\mathrm{D}(3.1)=\sqrt{(0,000-4,222)}{ }^{2}=4,222$

Perhitungan dilakukan sampai D (3.49).

Sehingga diperoleh hasil dari perhitungan data dengan titik pusat centroid setiap cluster sebagai berikut:

Tabel 3. Contoh Perhitungan Centroid Pada Setiap Cluster (Iterasi 1)

\begin{tabular}{|l|c|c|c|c|}
\hline \multicolumn{1}{|c|}{$\begin{array}{c}\text { Negara } \\
\text { Asal }\end{array}$} & $\begin{array}{c}\text { Total } \\
\text { Kematian }\end{array}$ & $\mathrm{C} 1$ & $\mathrm{C} 2$ & $\mathrm{C} 3$ \\
\hline Turkey & 4,222 & 980,778 & 101,017 & 4,222 \\
\hline Iran & 7,183 & 977,817 & 98,056 & 7,183 \\
\hline India & 3,434 & 981,566 & 101,805 & 3,434 \\
\hline China & 4,634 & 980,366 & 100,605 & 4,634 \\
\hline $\begin{array}{l}\text { Saudi } \\
\text { Arabia }\end{array}$ & 339 & 646,000 & 233,761 & 339,000 \\
\hline Pakistan & 985 & 0,000 & 879,761 & 985,000 \\
\hline Qatar & 16 & 969,000 & 89,239 & 16,000 \\
\hline Singapore & 22 & 963,000 & 83,239 & 22,000 \\
\hline Bangladesh & 386 & 599,000 & 280,761 & 386,000 \\
\hline UAE & 233 & 752,000 & 127,761 & 233,000 \\
\hline
\end{tabular}

Lalu hitung jarak terdekat dari cluster dengan menggunakan Euclidean Distance, seperti hasil dibawah ini:

Tabel 4. Jarak Terdekat (Iterasi 1)

\begin{tabular}{|c|c|c|c|c|}
\hline $\begin{array}{c}\text { Jarak } \\
\text { Terpendek }\end{array}$ & Hasil & C1 & C2 & C3 \\
\hline 4,222 & C3 & & & 1 \\
\hline 7,183 & C3 & & & 1 \\
\hline 3,434 & C3 & & & 1 \\
\hline 4,634 & C3 & & & 1 \\
\hline
\end{tabular}

\begin{tabular}{|c|c|c|c|c|}
233,761 & $\mathrm{C} 2$ & & 1 & \\
\hline 0,000 & $\mathrm{C} 1$ & 1 & & \\
\hline 16,000 & $\mathrm{C} 3$ & & & 1 \\
\hline 22,000 & $\mathrm{C} 3$ & & & 1 \\
\hline 280,761 & $\mathrm{C} 2$ & & 1 & \\
\hline 127,761 & $\mathrm{C} 2$ & & 1 & \\
\hline
\end{tabular}

Sehingga hasil dari perhitungan jarak data ke titik pusat cluster pada iterasi 1 yaitu:

Tabel 5. Hasil Cluster Pada Iterasi 1

\begin{tabular}{|c|c|}
\hline Cluster & Hasil \\
\hline C1 & 3 \\
\hline C2 & 4 \\
\hline C3 & 5 \\
\hline
\end{tabular}

e. Selanjutnya lakukan kembali langkah $4-5$ jika nilai hasil centroid dari iterasi 1 dengan nilai centroid selanjutnya bernilai sama ataupun nilai centroid sudah optimal dan posisi cluster tidak mengalami perubahan lagi maka proses iterasi berhenti. Akan tetapi jika posisi cluster masih berubahubah maka proses iterasi terus berlanjut sampai hasil bernilai sama.

f. Menghitung titik pusat terbaru dengan menggunakan hasil dari setiap cluster pada iterasi 1 . Berikut adalah contoh perhitungan titik pusat cluster baru pada iterasi 2 :

$$
\begin{aligned}
& \mathrm{C} 1=\frac{985+768+842}{\mathbf{3}}=865,000 \\
& \mathrm{C} 2 \\
& \frac{339+386+233+124+279+264+187+114+56}{9} \\
& =198,455 \\
& \mathrm{C} 2 \begin{array}{c}
4,222+7,183+3,434+4,634+16+22+339+16+22+1,242 \\
+12+35+
\end{array} \\
& \frac{30+43+13+1+14+4+4+9+26+17+12+9+7+2+2+0+6+}{30+1+0+0+3+0+0+0+0} \\
& =10,820 \quad 0
\end{aligned}
$$

\begin{tabular}{|c|c|c|c|c|c|}
\hline No & Negara & Hasil & $\mathrm{C} 1$ & $\mathrm{C} 2$ & $\mathrm{C} 3$ \\
\hline 1 & Turkey & $\mathrm{C} 3$ & 1 & & \\
\hline 2 & Iran & $\mathrm{C} 3$ & 1 & & \\
\hline 3 & India & $\mathrm{C} 3$ & 1 & & \\
\hline 4 & China & $\mathrm{C} 3$ & 1 & & \\
\hline 5 & Saudi Arabia & $\mathrm{C} 2$ & & & 1 \\
\hline
\end{tabular}

Setelah dilakukan perhitungan secara manual maka dihasilkan sebuah cluster jumlah kematian penderita covid-19.

Tabel 5. Hasil pengelompokkan Jumlah kematian penderita covid-19 


\begin{tabular}{|c|c|c|c|c|}
\hline 6 & Pakistan & $\mathrm{C} 1$ & 1 & \\
\hline 7 & Qatar & $\mathrm{C} 3$ & & 1 \\
\hline 8 & Singapore & C3 & & 1 \\
\hline 9 & Bangladesh & $\mathrm{C} 2$ & & 1 \\
\hline 10 & UAE & $\mathrm{C} 2$ & & 1 \\
\hline 11 & Indonesia & C3 & 1 & \\
\hline 12 & Kuwait & $\mathrm{C} 3$ & & 1 \\
\hline 13 & Israel & $\mathrm{C} 2$ & & 1 \\
\hline 14 & Japan & $\mathrm{C} 1$ & 1 & \\
\hline 15 & Philippines & $\mathrm{C} 1$ & 1 & \\
\hline 16 & S. Korea & $\mathrm{C} 2$ & & 1 \\
\hline 17 & Afghanistan & $\mathrm{C} 2$ & & 1 \\
\hline 18 & Bahrain & C3 & & 1 \\
\hline 19 & Malaysia & $\mathrm{C} 3$ & & 1 \\
\hline 20 & Kazakhstan & $\mathrm{C} 3$ & & 1 \\
\hline 21 & Oman & $\mathrm{C} 3$ & & 1 \\
\hline 22 & Armenia & $\mathrm{C} 3$ & & 1 \\
\hline 23 & Iraq & $\mathrm{C} 3$ & & 1 \\
\hline 24 & Azerbaijan & $\mathrm{C} 3$ & & 1 \\
\hline 25 & Thailand & $\mathrm{C} 3$ & & 1 \\
\hline 26 & Uzbekistan & $\mathrm{C} 3$ & & 1 \\
\hline 27 & Tajikistan & $\mathrm{C} 3$ & & 1 \\
\hline 28 & Kyrgyzstan & $\mathrm{C} 3$ & & 1 \\
\hline 29 & Maldives & $\mathrm{C} 3$ & & 1 \\
\hline 30 & Hong Kong & $\mathrm{C} 3$ & & 1 \\
\hline 31 & Sri Lanka & $\mathrm{C} 3$ & & 1 \\
\hline 32 & Lebanon & $\mathrm{C} 3$ & & 1 \\
\hline 33 & Cyprus & C3 & & 1 \\
\hline 34 & Georgia & $\mathrm{C} 3$ & & 1 \\
\hline 35 & Jordan & $\mathrm{C} 3$ & & 1 \\
\hline 36 & Taiwan & $\mathrm{C} 3$ & & 1 \\
\hline 37 & Nepal & C3 & & 1 \\
\hline 38 & Palestine & $\mathrm{C} 3$ & & 1 \\
\hline 39 & Vietnam & $\mathrm{C} 3$ & & 1 \\
\hline 40 & Myanmar & $\mathrm{C} 3$ & & 1 \\
\hline 41 & Yemen & $\mathrm{C} 3$ & & 1 \\
\hline 42 & Brunei & $\mathrm{C} 3$ & & 1 \\
\hline 43 & Mongolia & $\mathrm{C} 3$ & & 1 \\
\hline 44 & Cambodia & $\mathrm{C} 3$ & & 1 \\
\hline 45 & Syria & $\mathrm{C} 3$ & & 1 \\
\hline 46 & Macao & $\mathrm{C} 3$ & & 1 \\
\hline 47 & Timor-Leste & C3 & & 1 \\
\hline 48 & Bhutan & $\mathrm{C} 3$ & & 1 \\
\hline
\end{tabular}

49 Laos

\section{Tampilan RapidMiner}

Untuk mendapatkan hasil pengelompokkan pada tahap selanjutnya dilakukan dengan mengklik tanda panah biru yang terdapat di posisi tengah atas pada toolbar. Tahap ini akan menampilkan hasil akhir serta langkah terakhir dalam penggunaan tools rapidminer. Dapat dilihat pada gambar 1:

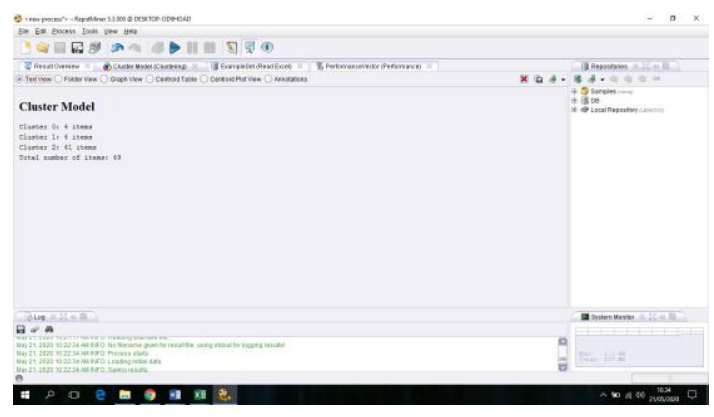

Gambar 1. Nilai Cluster Model

Keterangan :

Jumlah Cluster 1 (Tinggi) berjumlah 4 Items Jumlah Cluster 2 (Rendah) berjumlah 41 Items Jumlah Cluster 0 (Sedang) berjumlah 4 Items Jumlah keseluruhan items adalah 49.

Sehingga dapat diketahui hasil pengelompokkan rapidminer dapat dilihat pada gambar sebagai berikut :

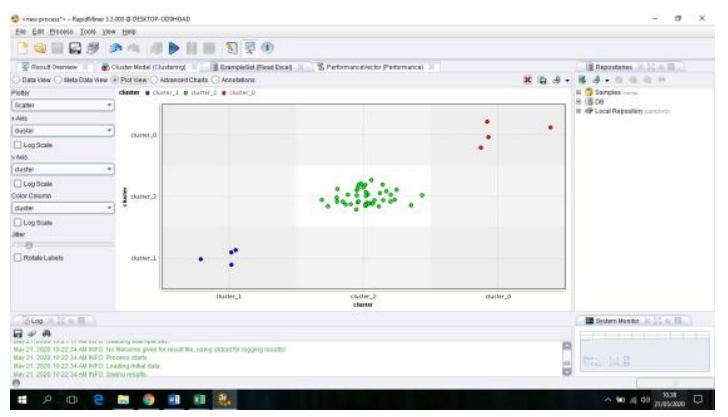

Gambar 2. Hasil Pengelompokan Berdasarkan pada gambar dapat dilihat bahwa kelompok tinggi memiliki 4 node, kelompok rendah memiliki 41 node, dan kelompok sedang 4 node.

\section{KESIMPULAN}

Adapun kesimpulan yang dapat di ambil pada tekhnik data mining dalam clustering total kematian penderita Covid-19 berdasaarkan negara-negara di Benua Asia dengan algoritma kmeans ini adalah sebagai berikut:

1. Algoritma k-means clustering ini dapat membantu peneliti mengelompokkan clustering total kematian penderita Covid-19 berdasaarkan negara-negara di Benua Asia. Dari data clustering total kematian penderita Covid-19 berdasarkan negara-negara di Benua Asia dapat di ketahui terdapat 4 negara 
dengan cluster tingkat tinggi yaitu: Turki, Iran, India dan China dengan cluster tingkat sedang sebanyak 4 negara yaitu : Pakistan, Indonesia, Jepang, dan Piliphina dan dengan cluster rendah adalah 41 negara lainnya.

2 Aplikasi rapidminer ini dapat membantu peneliti mengelompokkan total kematian penderita Covid-19 berdasaarkan negara di Benua Asia. Perhitungan manual algoritma $k$ means clustering dalam mengelommpokkan total kematian penderita Covid-19 berdasaarkan negara-negara di Benua Asia dan penerapan di Rapidminer menunjukkan hasil yang sama.

\section{REFERENSI}

Angga Ginanjar Mabrur, L. R. (2012). Penerapan Data Mining Untuk Memprediksi Kriteria Nasabah Kredit. Jurnal Komputer Dan Informatika (KOMPUTA), 1(1), 53-57.

Darmi, Y., \& Setiawan, A. (2016). Penerapan Metode Clustering K-Means Dalam. Y. Darmi, A. Setiawan, 12(2), 148-157.

Kristanto, N. H., A, A. C. L., \& S, H. B. (2016). Implemantasi K-Means Clustering untuk Pengelompokan Analisis Rasio Profitabilitas dalam Working Capital. Juisi, 02(01), 9-15.

Maulana, A., \& Fajrin, A. A. (2018). Penerapan Data Mining Untuk Analisis Pola Pembelian
Konsumen Dengan Algoritma Fp-Growth Pada Data Transaksi Penjualan Spare Part Motor. Klik - Kumpulan Jurnal Ilmu Komputer, 5(1), 27. https://doi.org/10.20527/klik.v5i1.100

Robani, M., \& Widodo, A. (2016). Algoritma KMeans Clustering Untuk Pengelompokan Ayat Al Quran Pada Terjemahan Bahasa Indonesia. Jurnal Sistem Informasi Bisnis, 6(2), 164. https://doi.org/10.21456/vol6iss2pp164-176

\section{PROFIL PENULIS}

Noviyanto, menyelesaikan pendidikan Program Sarjana Teknik Informatika pada Fakultas Teknologi Industri Universitas Gunadarma, dan melanjutkan Program Pascasarjana Magister Manajemen Sistem Informasi (S-2) pada Program Pasca Sarjana Universitas Gunadarma. Saat ini Penulis menjabat sebagai Kepala Sub Bagian Sistem Informasi dan Kerja Sama, Lembaga Layanan Pendidikan Wilayah III Jakarta, Kementerian Pendidikan dan Kebudayaan. Penulis juga mengajar sebagai Dosen NIDK pada Fakultas Ilmu Komputer Universitas Gunadarma. 